\title{
The influence of socio-economic variables on the occurrence of anxiety and depression disorders in women with the female genital tract tumours
}

\author{
Agnieszka Dombrowska-Pali', Dorota Rogala², Grażyna Gebuza ${ }^{1}$, Marzena Kaźmierczak', \\ Małgorzata Gierszewska', Estera Mieczkowska', Mirosława Ziółkowska ${ }^{3}$ \\ ${ }^{1}$ Department of Obstetric Care Basic, Faculty of Health Sciences, Collegium Medicum in Bydgoszcz, Nicolaus Copernicus \\ University in Toruń, Poland \\ 2 Department of Oncology, Radiotherapy and Gynecologic Oncology, Collegium Medicum Ludwika Rydygiera in Bydgoszcz, \\ Faculty of Health Sciences, Nicolaus Copernicus University in Toruń, Poland \\ ${ }^{3}$ Department of Psychiatric Nursing, Department of Conservative Nursing, Collegium Medicum Ludwika Rydygiera in \\ Bydgoszcz, Faculty of Health Sciences, Nicolaus Copernicus University in Toruń, Poland
}

Dombrowska-Pali A, Rogala D, Gebuza G, Kaźmierczak M, Gierszewska M, Mieczkowska E, Ziółkowska M. The influence of socio-economic variables on the occurrence of anxiety and depression disorders in women with the female genital tract tumours. Med Og Nauk Zdr. 2019; 25(2): 88-94. doi: $10.26444 /$ monz/109513

\begin{abstract}
Objectives.The aim of the study was to examine the level of anxiety and depression in female patients with genital tract tumours depending on socio-economic conditions, including: education, type of work performed, financial and housing situation.

Materials and Method.The research was conducted in the Gynaecological Oncology Clinic,at the Franciszek Łukaszczyk Oncology Centre in Bydgoszcz. The study was carried out on 73 patients with female genital tract tumours qualified for surgical treatment. The Hospital Anxiety and Depression Scale (HADS) and an own personal questionnaire were used in the study. $\mathrm{P} \leq 0.05$ was considered statistically significant.

Results.Analysis of research showed that socio-economic conditions influenced the occurrence of anxiety and depression disorders. The unemployed patients displayed a higher level of anxiety and depression compared to a group of patients performing intellectual and mixed work (mental and physical). In the examined group, the financial and housing situation also affects the level of anxiety and depression. Patients presenting a good financial situation had a statistically significantly lower level of anxiety and depression compared to patients with a medium financial situation. Analyzing the housing situation - patients with a very good housing situation had a lower level of anxiety and depression than patients with a good housing situation. There was no relationship between education and the occurrence of anxiety and depression in the study group.

Conclusions. Healthcare personnel should pay particular attention to unemployed patients whose financial and housing situation is unsatisfactory. This is a higher-risk group of patients who have a more significant risk of occurrence or intensification of depression and anxiety disorders.
\end{abstract}

\section{Key words}

depression, anxiety, socio-economic conditions, the female genital tract tumours

\section{INTRODUCTION}

Tumours of the female genital tract are one of the most frequent chronic conditions worldwide. The course of the disease affects the functioning of the internal organs and the mental sphere [1]. The occurrence of mental disorders in oncological patients is considered a common phenomenon. Depressive states occur four times more frequently in patients with female genital tract tumours than in the general population. Only $20 \%$ of individuals with depression disorders are diagnosed and receive proper treatment [2]. Most frequently, these patients experience depressive, anxiety and obsessive-compulsive disorders, as

Adress for correspondence: Agnieszka Dombrowska-Pali, Laboratory of Maternity Care, Collegium Medicum Ludwika Rydygiera, Bydgoszcz; Faculty of Health Sciences, Nicolaus Copernicus University, Toruń, Poland

E-mail: agnieszka.pali@cm.umk.pl

Received: 2 April 2019; Accepted: 20 May 2019 well as phobias [1]. Research shows that more and more individuals experience the fear of developing cancer, defined by the term of cancerophobia. The phenomenon of phobia sometimes occurs at the moment of preliminary diagnosis and does not resolve despite the positive results of medical examinations. Individuals suffering from cancerophobia interpret all the symptoms and reactions occurring in their bodies as symptoms of the neoplastic process. Such an advanced stage of the phobia being diagnosed with cancer may lead to serious emotional disorders resulting in confirming faith in the real existence of a neoplastic disease [3]. The conviction regarding the incidence of cancer may lead to the occurrence of delusions referred to as psychotic disorders, i.e. fixed delusional disorders of hypochondriacal content [1]. Studies show that the greater the social awareness regarding neoplastic diseases, the greater the level of anxiety and fear experienced. Individuals suffering from cancerophobia are traumatised. They spend a considerable amount of time on 
internet forums and other online portals. Usually, the initial anxiety turns into a paralysing fear which makes them less eager to visit doctors and undergo medical examinations. As a result, individuals suffering from cancerophobia do not undergo any medical examinations [4].

The International Statistical Classification of Diseases and Related Health Problems (ICD-10) developed by WHO is one of the binding systems for diagnosing depression. The diagnosis is based on an honest conversation between a psychiatrist and the patent, as well as on observing at least two out of three symptoms in the patient. The symptoms include: worsened mood, lack of interests, anhedonia, a loss of energy leading to an increased tiredness and lowered activity. The patient has to have experienced the listed incidents for at least two weeks [5]. Moreover, a patient with depressive disorders often complains about: weaker concentration and attention, sleep disorders, low self-esteem, decreased appetite, pessimistic scenarios for the future, suicidal thoughts and acts [5-6]. Grabińska et al conducted research among 122 patients ( 84 women and 38 men) to whom chemotherapy had been administered. The results showed that before being diagnosed with a neoplasm, $30 \%$ of the respondents suffered from a decrease in their mood and anxiety disorders, whereas, having being diagnosed with a neoplasm, the percentage was as much as $69 \%$. It is worth adding that only $10 \%$ of the individuals decided to turn to a psychiatrist or a psychologist; $24 \%$ admitted that they had wanted to do this but finally decided against it [2].

Oncological patients are exposed to a significant risk of the occurrence of depressive disorders. At the same time, depression makes them predisposed to the development of a neoplastic disease and has a negative effect on the course of treatment [7]. Research results show a significant influence of the patient's emotional condition on a successful coarse of the treatment for a neoplastic disease. Therefore, it is crucial to diagnose depression in ontological patients since it has a positive influence not only on the patients and their families, but also on the healthcare personnel [5, 8-9]. Moreover, individuals suffering both from a neoplastic disease and from depression demonstrate a greater tendency towards claims, expectations or complaints about ailments that are frequently unjustified. At the same time, such behaviour by patients can be inconvenient for doctors and nurses. Kryszkowski et al. state that depression makes the diagnostic process more difficult, increases the frequency of clinical consultations, prolongs the hospitalisation period and increases the number of suicidal attempts [10]. However, psychoneurological studies show that the experienced emotions significantly affect immunological actions [11]. Based on the research conducted by Luthendorf et al., the influence of the psychological attitude of female oncological patients on their immunological response, in particular, the cytotoxic response of natural killer cells (NK), was observed. The women suffering from depression had a significantly lower activity level of the cytotoxic anticancer NK cells than the patients whose psychological condition was classified as good. Therefore, it is very important not to worsen the functioning of the immunological system weakened as a result of a neoplastic disease [12].

A neoplastic disease is a source of numerous problems and suffering connected with the symptoms and treatment, as well as with the patient's adaptation to the disease in mental terms. The adaptation is expressed in the cognitive, emotional and behavioural spheres. It also constitutes an integral element of the patient's quality of life [13]. Adapting to the disease is a crucial index of the skill to battle the stress related to a neoplastic disease as well as its direct consequences, including: bad mood, pain, suffering and loneliness. It is vital that the patients have a positive attitude towards life, regardless of their life experiences, as well as shaping and developing their personal competencies helpful in coping with negative emotions or failures [14]. According to observations, a neoplastic disease is perceived as the greatest life threat, regardless of social status and socio-economic conditions [15]. More and more frequently oncological nursing carries out research aimed at identifying the factors determining the level of stress and anxiety in patients with a neoplastic disease. This allows for an early diagnosis of mental disorders and enables identifying patients who are at risk - those who are predisposed towards anxiety and depression disorders.

\section{OBJECTIVE}

The aim of the study was to examine the level of anxiety and depression in patients with female genital tract tumours, depending on socio-economic conditions and including: level of education, type of work performed, and financial and housing situation.

\section{MATERIALS AND METHOD}

The subjects were patients with a gynaecological neoplasm qualified for surgical treatment in the Clinic of Gynaecological Oncology at the Franciszek Łukaszczyk Oncology Centre in Bydgoszcz. 115 patients hospitalised in the clinic whose surgery was due to take place the following day were asked to participate in the study and fill-out a questionnaire, 35 women were rejected from the study and seven patients had to resign from participation due to increasing tiredness and irritation. Only those completed questionnaires filledout by $73 \%$ of the patients were taken consideration during the final statistical analysis. The most frequent reason for hospitalisation of the respondents was an ovarian neoplasm - 40 patients (54.8\%), next, endometrial cancer - 21 women (28.7\%); vulvar cancer, cervical cancer and uterine fibroids four patients each (5.5\%). The age of respondents ranged from $23-85.32$ respondents (48\%) had secondary level of education, 16 tertiary level of education (21.9\%), basic vocational and primary level of education - 12 and 8 individuals, respectively (16.4\% and 11\%). Two persons had post-secondary level of education (2.7\%). 42 (57.5\%) were economically active. 43 (59\%) rated their financial situation as good, 25 as average $(34.2 \%)$ and 5 individuals rated it as bad (6.8\%). 12 of the respondents (16.4\%) described their housing situation as very good, 55 stated it was good (75.3\%), 5 women stated it was average $(6.9 \%)$, and only one $(1.4 \%)$ reported that her situation was bad.

The study was conducted from August 2016 - March 2017. The Bioethics Committee of the Nicolaus Copernicus University in Toruń, Ludwik Rydygier Collegium Medicum, granted permission to carry out the project (No. BC 295/2016). Exclusion criteria included the occurrence of depression incidents during the interview and the fact of being treated 
for anxiety and/or depression. The patients were informed about the aim of the study and the manner in which it was to be conducted, as well as the possibility to resign from participation at any stage. Prior to participating in the study, the respondents signed a voluntary agreement.

Measures. A diagnostic survey was applied to carry out the research with the usage of own questionnaire and a standardised research tool. The Polish version of Hospital Anxiety Depression Scale (HADS) by M. Majkowicz, K. de Walden Gałuszko and G. Chojnacka-Szawłowska was used to assess the mental condition of the respondents The questionnaire is used in the case of ambulatory and hospitalised patients. It comprises of two subscales (14 questions) one of which regards anxiety (seven questions -HADS Anxiety); the other one concerns depression (seven questions- HADS Depression). The answers are given according to the Likert scale within the range of $0-3$ and the results scored in both subscales are added together. Results from 0-7 mean there is no occurrence of disorders. The thresholds are results from 8-10 and they are an indicator of minor anxiety disorders. Patients' with anxiety disorders of high intensity score is ranges from 11-21.

The calculations were performed using statistical package STATISTICA PL (version 10). The Kruskal-Wallis test and Mann-Whitney U test were used to analyse the results. The results regarding quantity parameters show the minimum (min) value, maximum ( $\max )$, the value of quartile (Q1, Me, Q3) the average $(\bar{x})$ and the standard deviation (SD). The graphs in the figures below present the median, the minimum and maximum value. $\mathrm{P}<0.05$ was considered statistically significant.

\section{RESULTS}

The statistical analysis regarding the occurrence of anxiety and depression in patients, taking into account their level of education, did not indicate any significant differences between the examined groups (Tab. 1).

Table 1. A descriptive and statistical analysis of the results regarding anxiety and depression with the usage of HADS, taking into account the type of education

\begin{tabular}{|c|c|c|c|c|c|c|c|c|c|c|}
\hline Education & $\mathrm{N}$ & $\bar{x}$ & SD & $\min$ & $\mathrm{Q}_{1}$ & $\mathrm{Me}$ & $\mathrm{Q}_{3}$ & $\max$ & $\begin{array}{l}\text { Kruskal- } \\
\text { Wallis test }\end{array}$ & $p$-value \\
\hline \multicolumn{11}{|c|}{ Scale of Anxiety } \\
\hline Primary & 8 & 8 & 3 & 3 & 5 & 9 & 11 & 12 & \multirow{4}{*}{3.762} & \multirow{4}{*}{0.288} \\
\hline Vocational & 12 & 12 & 6 & 3 & 7 & 13 & 17 & 20 & & \\
\hline Secondary & 37 & 9 & 5 & 1 & 5 & 8 & 12 & 18 & & \\
\hline Higher & 16 & 9 & 6 & 1 & 3 & 9 & 13 & 20 & & \\
\hline \multicolumn{11}{|c|}{ Scale of Depression } \\
\hline Primary & 8 & 10 & 3 & 2 & 9 & 11 & 12 & 13 & \multirow{4}{*}{1.713} & \multirow{4}{*}{0.633} \\
\hline Vocational & 12 & 9 & 6 & 0 & 5 & 9 & 14 & 17 & & \\
\hline Secondary & 37 & 8 & 4 & 1 & 3 & 8 & 11 & 15 & & \\
\hline Higher & 16 & 8 & 5 & 0 & 4 & 10 & 13 & 16 & & \\
\hline
\end{tabular}

Source: own work.

Using HADS, taking into account the level of education

The patients with a basic vocational level of education experienced the highest level of anxiety $(\bar{x}=12 ; \mathrm{Me}=13)$, their scores were a sign of severe anxiety disorders. The index of the occurrence of anxiety amongst the rest of respondents was at the threshold - the respondents with a higher level of education $(\bar{x}=9 ; \mathrm{Me}=9)$, with secondary level of education $(\bar{x}=9, \mathrm{Me}=8)$ and with primary level of education $(\bar{x}=8, \mathrm{Me}=9)$. The analysis regarding depression scale depending on level of education showed depression disorders of low intensity among the subject groups. Patients with an elementary level of education displayed the highest level of disorders $(\bar{x}=10 ; \mathrm{Me}=11)$, followed by the patients with a higher level of education $(\bar{x}=8 ; M e=10)$, basic vocational level of education $(\bar{x}=9, \mathrm{Me}=9)$ and secondary level of education $(\bar{x}=8, \mathrm{Me}=8)$.

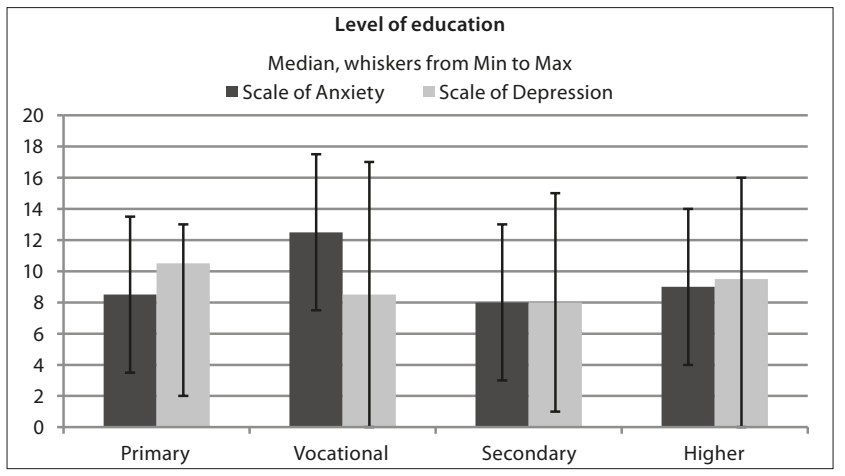

Figure 1. Distribution of scores regarding the anxiety and depression level based on HADS, taking into account level of education

Table 2 presents statistical analysis regarding the occurrence of anxiety and depression depending on the type of work performed. The results show that the occurrence of depression disorders amongst the respondents is statistically relevant in the case of the variable examined. The analysis of anxiety scale indicates a lack of statistical significance $(\mathrm{p}=0.253)$.

Table 2. A descriptive and statistical analysis of the results regarding anxiety and depression-based on the HADS, taking into account the type of work performed

\begin{tabular}{|c|c|c|c|c|c|c|c|c|c|c|}
\hline $\begin{array}{l}\text { Type of work } \\
\text { performed }\end{array}$ & $\mathrm{N}$ & $\bar{x}$ & SD & $\min$ & $\mathrm{Q}_{1}$ & $\mathrm{Me}$ & $\mathrm{Q}_{3}$ & $\max$ & $\begin{array}{l}\text { Kruskal- } \\
\text { Wallis test }\end{array}$ & $\mathrm{p}$-value \\
\hline \multicolumn{11}{|c|}{ Scale of Anxiety } \\
\hline Unemployed & 31 & 10 & 4 & 3 & 7 & 10 & 12 & 20 & \multirow{3}{*}{2.742} & \multirow{3}{*}{0.253} \\
\hline Mixed & 20 & 9 & 5 & 3 & 4 & 7 & 13 & 17 & & \\
\hline Intellectual & 22 & 8 & 6 & 1 & 2 & 9 & 13 & 18 & & \\
\hline \multicolumn{11}{|c|}{ Scale of Depression } \\
\hline Unemployed & 31 & 10 & 5 & 1 & 5 & 10 & 13 & 17 & \multirow{3}{*}{6.077} & \multirow{3}{*}{0.047} \\
\hline Mixed & 20 & 6 & 4 & 0 & 3 & 6 & 11 & 13 & & \\
\hline Intellectual & 22 & 8 & 4 & 0 & 4 & 8 & 12 & 15 & & \\
\hline
\end{tabular}

Source: own work.

Unemployed patients displayed the highest level of anxiety $(\bar{x}=10 ; \mathrm{Me}=10)$ and depression $(\bar{x}=10 ; \mathrm{Me}=10)$ in the study group. The results are a sign of disorders characterised with low intensity. The respondents performing mixed work (physical and intellectual) displayed the highest level of anxiety $(\bar{x}=9 ; \mathrm{Me}=7)$ regarding the level of depression $(\bar{x}=6 ; \mathrm{Me}=6)$. The level of anxiety and depression in patients performing intellectual work was at the same level $(\bar{x}=8)$ $\mathrm{Me}=9$ vs $\mathrm{Me}=8$, respectively (Fig. 2). 




Figure 2. Distribution of scores regarding anxiety and depression level, based on HADS, taking into account the type of worked performed

Numerous statistically relevant differences were observed between the occurrence of depression and anxiety depending on the financial situation of the respondents (Tab. 3). This confirms the posed hypothesis that one's financial situation has an influence on the level of anxiety and depression.

Table 3. A descriptive and statistical analysis of the results regarding anxiety and depression based the HADS, taking into account the financial situation of the respondents

\begin{tabular}{lcccccccccc}
\hline $\begin{array}{l}\text { Financial } \\
\text { situation }\end{array}$ & $\mathrm{N}$ & $\mathrm{SD}$ & $\min$ & $\mathrm{Q}_{1}$ & $\mathrm{Me}$ & $\mathrm{Q}_{3}$ & $\max$ & $\begin{array}{c}\text { Mann- } \\
\text { Whitney test }\end{array}$ & p-value \\
\hline Scale of Anxiety & & & & & & & & & \\
\hline Good & 43 & 6 & 4 & 0 & 3 & 5 & 10 & 14 & -4.816 & $<\mathbf{0 . 0 0 1}$ \\
\hline Average & 30 & 11 & 3 & 1 & 9 & 12 & 14 & 17 & & \\
\hline Scale of Depression & & & & & & & & \\
\hline Good & 43 & 8 & 5 & 1 & 3 & 7 & 11 & 20 & -3.055 & $\mathbf{0 . 0 0 2}$ \\
\hline Average & 30 & 11 & 5 & 2 & 7 & 12 & 15 & 20 & & \\
\hline
\end{tabular}

Source: own work.

The results regarding the anxiety scale show that patients with an average financial situation experienced a higher level of anxiety $(\bar{x}=11 ; \mathrm{Me}=12)$ than the patients whose financial situation was good $(\bar{x}=6 ; \mathrm{Me}=5)$. Analysis of the depression scale showed that the patients s whose financial situation was good, displayed a lover level of depression $(\bar{x}=8$; $\mathrm{Me}=7$ ), compared to the patients whose financial situation was average $(\bar{x}=11 ; \mathrm{Me}=12)$.

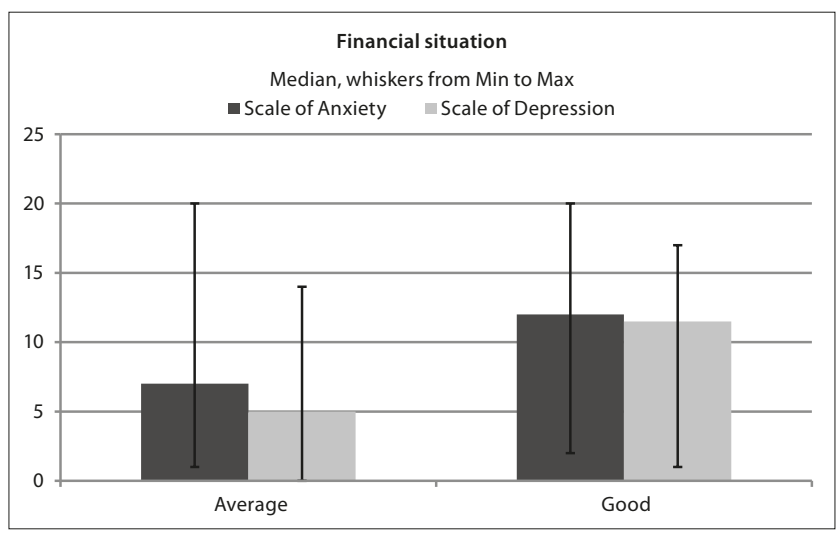

Figure 3. Distribution of scores regarding the level of anxiety and depression based on HADS, taking into account the financial situation
Numerous statistically relevant differences were observed between the occurrence of anxiety and depression depending on the housing situation of the respondents (Tab. 4).

Table 4. A descriptive and statistical analysis of the results regarding anxiety and depression based on the HADS, taking into account the housing situation of the respondents

\begin{tabular}{|c|c|c|c|c|c|c|c|c|c|c|}
\hline $\begin{array}{l}\text { Housing } \\
\text { situation }\end{array}$ & $\mathrm{N}$ & $\bar{x}$ & SD & $\min$ & $\mathrm{Q}_{1}$ & $\mathrm{Me}$ & $\mathrm{Q}_{3}$ & $\max$ & $\begin{array}{c}\text { Mann- } \\
\text { Whitney test }\end{array}$ & $\mathrm{p}$-value \\
\hline \multicolumn{11}{|c|}{ Scale of Anxiety } \\
\hline Good & 61 & 10 & 5 & 1 & 6 & 10 & 13 & 20 & \multirow{2}{*}{3.490} & \multirow{2}{*}{$<0.001$} \\
\hline Very good & 12 & 6 & 5 & 1 & 3 & 5 & 7 & 17 & & \\
\hline \multicolumn{11}{|c|}{ Scale of Depression } \\
\hline Good & 61 & 9 & 4 & 1 & 6 & 10 & 12 & 17 & \multirow{2}{*}{2.367} & \multirow{2}{*}{0.018} \\
\hline Very good & 12 & 4 & 4 & 0 & 1 & 4 & 5 & 11 & & \\
\hline
\end{tabular}

Source: own work

The respondents with a good housing situation had significantly higher results $(\bar{x}=10 ; \mathrm{Me}=10)$ regarding the anxiety scale in comparison with the patients whose housing situation was very good $(\bar{x}=6 ; \mathrm{Me}=5)$. The values are four points higher as far as the averages are concerned, and by five points higher regarding the medians (Fig. 4). Comparison between the groups regarding the anxiety scale indicted the occurrence of statistically significant differences. This confirms the posed hypothesis that the housing situation had an influence on the level of anxiety and depression. The second analysis regarding the comparison concerning the scale of depression also showed the occurrence of statistically significant differences between the analysed groups. The patients with a good housing situation had a significantly higher level of depression $(\bar{x}=9 ; \mathrm{Me}=10)$, compared to patients whose housing situation is very $\operatorname{good}(\bar{x}=4 ; \mathrm{Me}=4)$. The difference in results was about five points, both for the average and for the median. The results confirmed the posed hypothesis that the housing situation has an influence on the level of anxiety and depression.

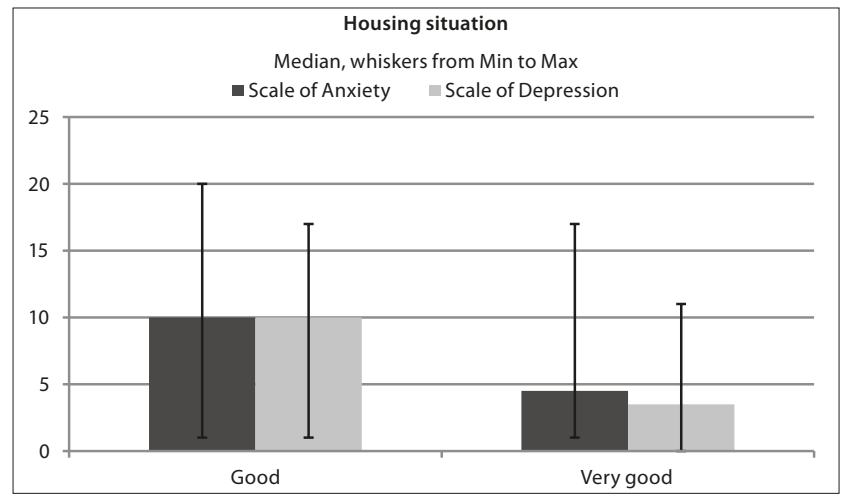

Figure 4. Distribution regarding the level of anxiety and depression, based on HADS, taking into account one's housing situation

\section{DISCUSSION}

Tumours of the female genital tract present a great source of stress and negative emotions for the patients. They are considered the most stressful of all diseases [17]. The respondents who took part in the study suffered from 
somatic ailments as well as from anxiety connected with the diagnosis, hospitalisation, treatment, complications and possible relapse of the disease. Patients with female genital tract tumours are particularly prone to emotional disorders due to the location of the tumours. For to this reason, studies aimed at identifying additional factors which are yet another source of patient's anxiety and depression are conducted more and more frequently [18]. The socio-economic determinant of the emotional reaction in oncologial patients most often mentioned in the literature is age. It was observed that the more advanced the patient's age, the stronger her emotional reaction, characterised by symptoms of anxiety and depression $[15,18,19]$. The results of own research present other determinants influencing the level of anxiety and depression in patients with female genital tract tumours. The factors influencing the occurrence of mental disorders are economic activity, financial and housing situations.

Analysis of own research showed that the fact of being unemployed predisposes to the occurrence of depression. The respondents who did not work displayed a higher level of anxiety in comparison with working individuals. This can be connected with the fact that patients who do not work are usually older, retired, or receiving a disability pension. A tendency can be observed in these individuals towards stronger anxious reactions. II is often the case that older patients are unable to adapt to the situation in which they find themselves. Consequently, stronger symptoms of anxiety and uncertainty resulting from the disease can be observed. In different studies in which the subjects were unemployed individuals suffering from leukaemia, a much higher level of depression was observed compared to those patients who were economically active. Cieślik concluded that enabling patients suffering from leukaemia to be economically active would significantly influence the improvement and maintenance of their quality of life. Due to this fact, patients whose economic activity is limited display a considerably higher level of depression than those patients who are economically active [20]. The studies by Inhestern et al. also confirm that the fact of being unemployed results in worse mental health. Moreover, they claim that the diagnosis of female genital tract tumours has a greater influence on the occurrence of depression of greater intensity, compared to patients diagnosed with breast cancer [21]. However, Zdończyk, when measuring the quality of life of women who underwent mastectomy, observed a natural dependence. He noticed that women who were economically active were much more physically fit than women who are retired, pensioners, and not economically active. This also affects their mental functioning [22].

Socio-economic factors, including financial and housing conditions, have a considerable influence on the occurrence of mental disorders. This is confirmed by the analysis of this study since the patients who described their housing situation as very good had a significantly lower level of anxiety and depression than the patients whose housing situation was good. Housing conditions certainly affect the patents' general assessment of the quality of life. This determines their mental health to a certain extent. It can be assumed that the level of the patient's housing situation is affected by yet another factor of anxiety and depression that was analysed in the study the financial situation. Analysis of the research confirmed that the patients who rated their financial situation lower, indeed had a higher level of anxiety and depression than the patients who rated their financial situation higher. This result corresponds to the results of other studies. Kurowska, in her research, also indicated the following dependency: the worse the economic situation of oncological patients, the proportionally higher their level of anxiety and depression [23]. The results of studies conducted by Srivastava also confirm that patients whose monthly income was low and who lacked financial support, experienced anxiety more often and depression occurred more frequently in them [16]. According to Hassan et al., patients with breast cancer whose economic status was lower, required greater support and care due to the fact of a greater risk of the occurrence of depression, in comparison with patents whose socio-economic status was satisfactory [24]. However, Inhestern et al., when analysing the factors determining the occurrence of anxiety and depression, concluded that those patients in whom the female genital tract tumours were diagnosed, displayed a statistically relevant level of anxiety and depression compared to patients with breast cancer [21].

The last analysed factor that could possibly have an influence on the level of anxiety and depression was level of education. The analysis of own research regarding the occurrence of anxiety and depression in women with female genital tract tumours taking into accord the patient's level of education, did not demonstrate any statistical relevance. The lack of substantial dependencies between the level of anxiety and level of education was also observed in studies conducted among women who had undergone mastectomy [15]. Sirvastava presents contrary observations; in his research he proved that there is a relationship between level of education and the occurrence of depression and anxiety disorders. Using the HADS, he concluded that those individuals whose level of education was lower experienced anxiety and depression of greater intensity [16]. Other studies show that level of education has no influence on the feeling of being able to deal with everything effectively in the face of a neoplastic disease [25], which, in turn, can result in a worse mental condition of the patients.

One should also consider whether among the 42 patients who did not agree to participate in the study or abandoned it, were patients with a high level of anxiety and/or depression. The very fact of not agreeing to participate in the study may be a sign of withdrawal from social contacts. This, in turn, may be a significant symptom of mental disorder. The research conducted shows that the assessment of the impact of socioeconomic factors on the occurrence of depression and anxiety disorders in patients with the female genital tract tumours, constitutes a significant element of the nursing diagnosis. One should consider conducting further studies that would include a more numerous study group. This, in turn, would enable analysing the subject in more detail - assessment of socio-economic conditions determining the occurrence or the intensity of anxiety and/or depression.

\section{CONCLUSIONS}

1. The assessment of anxiety and depression constitutes a significant element of clinical research conducted amongst patients with female genital tract tumours. This assessment is a vital source of information regarding the patient during causal and symptomatic treatment of neoplasms. 
2. The occurrence of depression in oncological patients is influenced by their unsatisfactory housing and financial situation, as well as the fact that they are unemployed.

3. A significant influence of unsatisfactory housing and financial situation was observed regarding the occurrence of anxiety.

\section{REFERENCES}

1. Sesiuk A, Rzepiela L. Selected psychiatric disorders in patients with cancer [Wybrane zaburzenia psychiczne w przebiegu chorób nowotworowych]. Psychiatr Psychol Klin. 2016; 16(1): 21-26. DOI: 10.15557/PiPK.2016.0004.

2. Grabińska K, Szewczyk - Cisek I, Hernik P, Mykała - Cieśla J, Kaziród D. Psychosocial problems and needs of patients undergone chemotherapy [Problemy i potrzeby psychosocjalne pacjentów poddanych chemioterapii onkologicznej]. Psychoonkologia. 2011; 15(2): 39-47.

3. Borowicz K. Cancerophobia - fear of cancer [Cancerofobia - strach przed rakiem]. http://www.zwrotnikraka.pl/cancerofobia/ (Retrieved 2018.02.26)

4.Dębski A. Cancerophobia is more dangerous than cancer [Kancerofobia groźniejsza niż rak]. http://www.medonet.pl/psyche/ psychologia,kancerofobia-grozniejsza-niz-rak,artykul,1715533.html (Retrieved 2018.10.29).

5. Murawiec S. Depression in patients with cancer. Diagnosis and treatment in clinical practice [Depresja u osób z chorobą nowotworową. Rozpoznawanie i leczenie - aspekty praktyczne]. OncoReview. 2012; 2(3): 201-208.

6. Fagundes C, LeRoy A, Karuga M. Behavioral symptoms after breast cancer treatment: a biobehavioral approach. JPM. 2015; 5(4): 280-295

7. Jarema M, Rabe - Jabłońska J. Psychiatry. Textbook for medical students [Psychiatria. Podręcznik dla studentów medycyny]. Warszawa: Wydawnictwo Lekarskie PZWL, 2011.

8. Bodurka-Bevers D, Basen-Enbquist K, Carmadack CL, Fitzgerald MA., Wolf JK, de Moor C, et al. Depression, anxiety and quality of life in patients with epithelial ovarian cancer. Gynecol Oncol. 2000; 78(1): 302-308, DOI:10.1006/gyno.2000.5908.

9. Car J, Życińska J, Lasota W. Assessment of psychological distress and depression in cancer patients. Prz Epidemiol. 2012; 4(66): 689-695.

10. Kryszkowski W, Bobińska K, Florkowski A, Pluta P, Gottwald L, Gałecki P. Influence of antidepressant pharmacotherapy on the course of cancer. Psychiatr Pol. 2012; 46(1): 85-94.

11. Carson RC, Butcher JN, Mineka S. Psychologia zaburzeń. Gdańsk: Gdańskie Wydawnictwo Psychologiczne, 2011.

12. Nowicka A, Rogala E, Wertel I. The immune system in the ovarian tumoran ally or foe? [Układ immunologiczny w chorobie nowotworowej jajnika - sojusznik czy wróg?]. Ginekol Dypl. 2011; 13: 28-32.
13. Kulpa M, Owczarek K, Stypuła-Ciuba B. The impact of menta adjustment to cancer to the quality of life [Przystosowanie psychiczne do choroby nowotworowej a jakość życia uwarunkowana stanem zdrowia u chorych onkologicznych]. Med Paliat. 2013; 5(3): 106-113.

14. Kozak G. Different strategies of managing neoplasia in the course of chosen cancers [Zróżnicowanie strategii radzenia sobie z nowotworem chorych w przebiegu wybranych nowotworów złośliwych]. Anest Ratow. 2012; 6: 162-170.

15. Stępień RB. Socio-demographic determinants of anxiety and depression levels of women after radical surgical treatment for breast cancer mastectomy [Uwarunkowania społeczno-demograficzne poziomu lęku i depresji u kobiet po radykalnym leczeniu chirurgicznym raka piersi — mastektomii]. Probl Pielęg. 2017; 15(1): 20-25.

16. Srivastava V, Ansari MA, Kumar A, Shah AG, Meena RK, Sevach P, et al. Study of Anxiety and Depression among Breast Cancer Patients from North India. Clin Psychiatry. 2016; 2(1). DOI: 10.21767/24719854.100017.

17. Szwat B, Słupski W, Krzyżanowski D. Ways of coping with cancer and feeling of depression and pain intensity in patients receiving palliative care [Sposoby radzenia sobie $\mathrm{z}$ chorobą nowotworową a poczucie depresji i nasilenie bólu u chorych objętych opieką paliatywną]. Piel. Zdr. Publ. 2011; 1(1): 35-41.

18. Goker A, Guvenal T, Yanikkerem E, Turhan A, Koyuncu FM. Quality of life in women with gynecologic cancer in Turkey. Asian Pac J Cancer Prev. 2011; 12(11): 3121-3128.

19. Chakalova G. Management of Gynecological Cancer Patients Older than 70 Years of Age. IJGE. 2015; 9(2): 93-97. DOI: https://doi.org/10.1016/j. ijge.2015.05.006

20. Cieślik, A. The influence of the professional activity on quality of life of patients with leukemia [Wpływ aktywności zawodowej na jakość życia chorych na białaczki]. Stud Med. 2008; 9: 27-32.

21. Inhestern L, Beierlein V, Bultmann JC, Möller B, Romer G, Koch $\mathrm{U}$, et al. Anxiety and depression in working-age cancer survivors: a register-based study. BMC Cancer. 2017; 17(1): 347. DOI: 10.1186/ s12885-017-3347-9.

22.Zdończyk SA, Rynkiewicz M. Quality of life of women after surgical treatment of breast cancer [Jakość życia kobiet po leczeniu operacyjnym raka gruczołu piersiowego]. Pielęg Pol. 2015; 2(56): 153-158.

23. Kurowska K, Brojakowska M. Support and quality of life In people with chronic obstructive pulmonary disease [Wsparcie a jakość życia osób z przewlekłą obturacyjną chorobą płuc]. Now Lek. 2010; 79(6): 438-444.

24. Hassan MR, Shah SA, Ghazi HF, Mohd Mujar NM, Samsuri MF, Baharom N. Anxiety and Depression among Breast Cancer Patients in an Urban Setting in Malaysia. Asian Pac J Cancer Prev. 2015; 16(9): 4031-4035.

25. Gapińska B, Tartas M, Walkiewicz M, Majkowicz M. Self-efficacy and anxiety and depression in patients with colostomy [Poczucie własnej skuteczności a lęk i depresja u pacjentów po zabiegu wyłonienia stomii jelitowej]. Współcz Onkol. 2008; 12(2): 84-89. 


\title{
Wpływ zmiennych socjoekonomicznych na wystąpienie zaburzeń lękowych i depresyjnych u kobiet z chorobą nowotworową narządu rodnego
}

\author{
I Streszczenie \\ Cel pracy. Celem podjętych badań była ocena poziomu lęku i depresji u pacjentek ze złośliwym nowotworem narządu \\ rodnego w zależności od uwarunkowań socjoekonomicznych, takich jak: wykształcenie, rodzaj wykonywanej pracy, sytuacja \\ finansowa i mieszkaniowa. \\ Materiał i metody. Badania zostały przeprowadzone na Oddziale Klinicznym Ginekologii Onkologicznej Centrum Onkologii \\ im. prof. Franciszka Łukaszczyka w Bydgoszczy. Objęto nimi 73 pacjentki z nowotworem narządu rodnego zakwalifikowane \\ do leczenia operacyjnego. W badaniu wykorzystano kwestionariusz do oceny nasilenia lęku i depresji HADS oraz ankietę \\ osobową własnej konstrukcji. Jako poziom istotności przyjęto $p \leq 0,05$. \\ Wyniki. Analiza badań wskazuje, że warunki socjoekonomiczne mają wpły w na wystąpienie zaburzeń lękowych i depresyjnych. \\ Pacjentki bezrobotne prezentowały wyższy poziom lęku i depresji w porównaniu z grupą pacjentek wykonujących pracę \\ umysłową i pracę mieszaną (umysłową i fizyczną). W badanej grupie na poziom lęku i depresji ma wpływ również sytuacja \\ finansowa i mieszkaniowa. Pacjentki prezentujące dobrą sytuację finansową mają istotnie statystycznie niższy poziom lęku \\ i depresji w porównaniu z pacjentkami ze średnią sytuacją finansową. Natomiast analizując sytuację mieszkaniową, należy \\ stwierdzić, że pacjentki z bardzo dobrą sytuacją mieszkaniową mają niższy poziom lęku i depresji niż pacjentki z dobrą \\ sytuacją mieszkaniową. W badanej grupie nie stwierdzono jednak zależności między wykształceniem a wystąpieniem cech \\ lęku i depresji. \\ Wnioski. Personel medyczny szczególną uwagę powinien zwrócić na pacjentki niepracujące, z niesatysfakcjonującą sytuacją \\ finansową i mieszkaniową. Jest to grupa pacjentek podwyższonego ryzyka, a zatem taka, w której istnieje większe ryzyko \\ wystąpienia i/lub nasilenia zaburzeń depresyjnych i lękowych.
}

\section{Słowa kluczowe}

depresja, lęk, warunki socjoekonomiczne, nowotwór narządu rodnego 